\section{Diagnostic and treatment challenges, a new section in $\mathrm{N} 2$}

Neurol Neuroimmunol Neuroinflamm November 2018 vol. 5 no. 6 e511. doi:10.1212/NXI.0000000000000511

This issue of Neurology ${ }^{\circledR}$ Neuroimmunology and Neuroinflammation (N2) includes a new section named "Diagnostic and Treatment Challenges" that contains a classical case-report presentation and multidisciplinary discussion among physicians, with the aim to underscore the "pearls," "pitfalls," and fundamental principles that can be effectively integrated in our practices. This educational offering will include cases selected from the Conference Webinars presented by the National Multiple Sclerosis Society Clinical Fellows and other submissions from our readers of similarly formulated case reports and discussions from forums such as grand rounds or multidisciplinary conferences. Cases will include patients with any type of neuroimmunologic diseases. The introductory case in this issue of N2 "A young man with numbness in arms and legs" exemplifies how this section is envisioned. ${ }^{1}$

Gender differences occur in many autoimmune diseases including those that affect the nervous system. Defining and understanding gender differences will lead to improved health care for all patients. The study by Lee et al. ${ }^{2}$ explores gender differences in the adverse effects of prednisone in a cohort of patients with myasthenia gravis. Almost 2,000 patients enrolled in the Myasthenia Gravis Registry, a nationwide database, were sent a short survey about their disease and use of steroids, and 398 patients (21\%) responded. About two-thirds had or were taking steroids while the remaining had never taken steroids. Although prednisone adverse events were commonly reported by both sexes, they were more frequently reported in women ( $95 \%$ vs $77 \%$ ). Women also reported more adverse events that were intolerable as compared with men ( $81 \%$ vs $50 \%)$, and this was associated with women being less willing to accept an increase of their steroid dose. The reasons for these gender differences will need to be fully elucidated but appear to include differences between women and men in their tolerance of adverse events related to appearance and social interactions. The authors also raise an immediately addressable possibility. They found that women and men had comparable peak steroid dosage suggesting that dosing was not based on ideal body weight. This would likely result in women receiving a higher steroid dose (on a perweight basis) leading to more adverse events. Additionally, not only did the steroid dose and dosing schedule vary (reflecting the lack of consensus guidelines) but most of the patients were on a daily dosing schedule that is more likely to be associated with adverse events than alternate day dosing.

In a retrospective cohort study, Kleiter et al. ${ }^{3}$ set out to determine whether 1 of 2 apheresis techniques, therapeutic plasma exchange (PE) or immunoadsorption (IA), was superior in treating attacks of neuromyelitis optica spectrum disorders (NMOSD) and to identify predictive factors for complete response. Patients were identified from the German Neuromyelitis Optica Study Group registry that includes patients with NMOSD diagnosed according to the 2006 Wingerchuk criteria or with aquaporin-4 antibody seropositive NMOSD. Attacks were defined following the definition for multiple sclerosis (MS) relapses, as objective neurologic worsening lasting for at least 24 hours in the absence of fever or infections, and occurring more than 30 days after a previous attack. Both PE and IA were similarly effective and induced at least partial

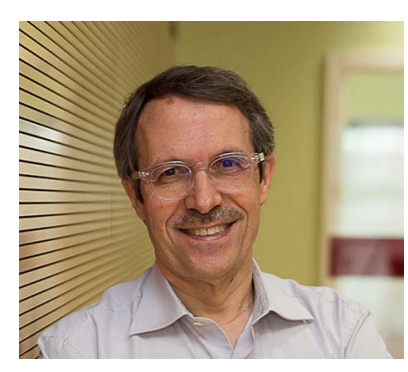

MORE ONLINE

๑ Editor Summary

NPub.org/N2/edsum 
remission in the majority of attacks, regardless of whether they were used as first- to fifth-line therapy, with no difference in the change of Expanded Disability Status Scale (EDSS) score between the 2 techniques. However, complete remission only occurred when aphesis was initiated within days of attack onset with a stepwise decline in improvement with apheresis delay. Strong predictors for complete remission were the use of apheresis therapy as first-line therapy, time from onset of attack to start of therapy (in days), the presence of aquaporin-4 antibodies, and monofocal attack manifestation.

The innate immune system uses DNA sensing pathways to detect the presence of DNA in the cytoplasm and, in response, lead to the activation of defense mechanisms, such as increased interferon expression. DNA sensing plays a role in the response to DNA virus, in tumor surveillance, and cellular senescence. However, aberrant DNA sensing can result in an overactive immune system leading to autoimmune disease, as have been shown for Aicardi-Goutieres syndrome. The study by Morgensen et $\mathrm{al}^{4}$ in this issue of N2 provides a novel association between defects in DNA sensing and CNS disease. The authors describe a set of monozygotic twins with recurrent CNS vasculitis and stroke-like episodes that were associated with varicella zoster virus (VZV) reactivation in the CSF. Both patients were found to have a heterozygous missense mutation in the POL3RF subunit of the cytosolic DNA sensor POL III. The authors show that this mutation results in impaired antiviral responses and increased VZV replication in patients' peripheral blood mononuclear cells compared to controls. Both patients had clinical responses to acyclovir and corticosteroids but experienced symptom recurrence and new MRI lesions when acyclovir was discontinued. This study provides further evidence of the importance of DNA sensors and of their emerging role in neuroinflammatory and infectious diseases. The identification of aberrant DNA sensing pathways is an important step in developing novel therapeutic targets.
The other articles in this issue of $\mathrm{N} 2$ also deserve attention and cover a wide range of topics including among others the demonstration that incorporating in-home telemedicine in the care of patients with MS reduces travel and caregiver burden and enables more efficient and convenient follow-up care, and another study showing that long-term use of rituximab in patients with NMOSD is associated with the risk of developing hypogammaglobulinemia and related complications.

\section{Study funding}

No targeted funding reported.

\section{Disclosure}

J. Dalmau is the editor of Neurology : Neuroimmunology and Neuroinflammation, is on the editorial board for Neurology UpToDate; holds patents for and receives royalties from Ma2 autoantibody test, NMDA receptor autoantibody test, $\mathrm{GABA}(\mathrm{B})$ receptor autoantibody test, $\mathrm{GABA}(\mathrm{A})$ receptor autoantibody test, DPPX autoantibody test, and IgLON5 autoantibody test; and receives research support from Euroimmun, NIH, Fundació CELLEX, Instituto Carlos III (CIBERER, and Fondo de Investigaciones Sanitarias). Full disclosure form information provided by the authors is available with the full text of this article at Neurology.org/NN.

Received September 11, 2018. Accepted in final form September 11, 2018.

\section{References}

1. Romeo A, Lisak RP, Meltzer E, et al. A young man with numbness in arms and legs From the National Multiple Sclerosis Society Case Conference Proceedings. Neurol Neuroimmunol Neuroinflamm 2018;5:e509. doi: 10.1212/NXI.0000000000000509.

2. Lee I, Kaminski HJ, McPherson T, Feese M, Cutter GR. Gender differences in prednisone adverse effects: survey result from the MG registry. Neurol Neuroimmunol Neuroinflamm 2018;5:e507. doi: 10.1212/NXI.0000000000000507.

3. Kleiter I, Gahlen A, Borisow N, et al. Apheresis therapies for NMOSD attacks: a retrospective study of 207 therapeutic interventions. Neurol Neuroimmunol Neuroinflamm 2018;5:e504. doi: 10.1212/NXI.0000000000000504.

4. Mogensen T, Carter-Timofte M, Hansen A, et al. Varicella-zoster virus CNS vasculitis and RNA polymerase III gene mutation in identical twins. Neurol Neuroimmunol Neuroinflamm 2018;5:e500. doi: 10.1212/NXI.0000000000000500. 


\section{Neurology \\ Neuroimmunology \& Neuroinflammation}

Diagnostic and treatment challenges, a new section in N2

Josep Dalmau

Neurol Neuroimmunol Neuroinflamm 2018;5;

DOI 10.1212/NXI.0000000000000511

This information is current as of October 23, 2018

\section{Updated Information \& Services}

References

Permissions \& Licensing

Reprints including high resolution figures, can be found at:

http://nn.neurology.org/content/5/6/e511.full.html

This article cites 4 articles, 3 of which you can access for free at: http://nn.neurology.org/content/5/6/e511.full.html\#\#ref-list-1

Information about reproducing this article in parts (figures,tables) or in its entirety can be found online at:

http://nn.neurology.org/misc/about.xhtml\#permissions

Information about ordering reprints can be found online: http://nn.neurology.org/misc/addir.xhtml\#reprintsus

Neurol Neuroimmunol Neuroinflamm is an official journal of the American Academy of Neurology.

Published since April 2014, it is an open-access, online-only, continuous publication journal. Copyright

Copyright $\odot 2018$ The Author(s). Published by Wolters Kluwer Health, Inc. on behalf of the American Academy of Neurology.. All rights reserved. Online ISSN: 2332-7812.

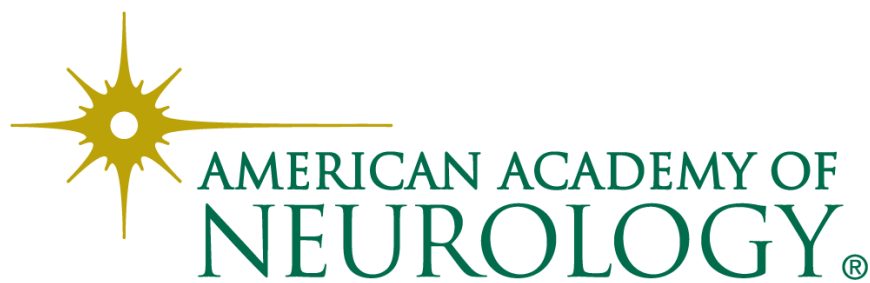

